\title{
The Effect of TPS-Type Cooperative Learning Model on Student Learning Motivation at STIMI Meulaboh
}

\author{
Nur Fajri $^{\mathrm{a}, 1,{ }^{*}}$, Eka syani $^{\mathrm{b}, 2}$, Yenni Muflihan ${ }^{\mathrm{b}, 3}$ \\ ${ }^{a, b}$ STIMI Meulaboh, Meulaboh-Tapaktuan Streets, langung, 23681, Indonesia \\ Inurfajri.ifar@gmail.com*; ${ }^{2}$ ekasyani@yahoo.co.id; ${ }^{3}$ yennimuflihan@gmail.com
}

\section{ARTICLE INFO}

Article history:

Accepted

Keywords:

Learning Effect

Student motivation
TPS type cooperative learning

\section{ABSTRACT}

Successful learning is learning that can make students motivated, fun and comfortable in the teaching and learning process. Cooperative learning is one way for lecturers so that students can enjoy learning. Therefore, it is very important for lecturers to create fun and comfortable student learning without pressure. The purpose of this study was to determine the effect of the application of the TPS type cooperative learning model on students' learning motivation at STIMI Meulaboh. This type of research is experimental research by applying the TPS type cooperative learning model and the results are by distributing questionnaires and observations. The results of this study are the TPS type cooperative learning model has an effect on students' learning motivation. Therefore, it can be said that the TPS type of cooperative learning model is feasible to be used in the Economics I statistics learning process in the classroom to improve students' understanding and quality of learning.

Copyright (C) 2021 Politeknik Aceh Selatan. All rights reserved.

\section{Introduction (Heading 1)}

Good learning is learning that is structured as well as possible to generate student learning motivation. According to [1] learning is an effort (teaching) that can encourage students to learn. So it can be said that learning in schools is a type of activity or process of interaction between educators and students.

The Effect of the TPS Type Cooperative Learning Model on Student Learning Motivation Based on observations made at one of the STIMI Meulaboh campuses for the 2019-2020 academic year on Economic Statistics I learning activities, problems were found in the learning process. The class observed was the second semester students of STIMI Meulaboh in the Economic Statistics I course. During the implementation of the Economic Statistics, learning process during the learning process, it showed that most of the students seemed less interested and tended to be less active. One of the problems that occur according to [2] states that the lack of understanding of educators to design learning techniques/methods can dig students' self-confidence so that they are less active in learning.

One way that lecturers can use to activate the teaching and learning process in the classroom is by applying a cooperative learning model. In this learning model, students are not placed as objects of learning, but as subjects in learning activities. In this study, researchers took cooperative learning, namely think-pair-share (TPS) type of cooperative learning.

TPS type cooperative learning is cooperative learning designed to influence student interaction patterns, the structure developed is intended as an alternative to the traditional 
classroom structure. TPS type cooperative learning begins by giving problems to students (think) then solving problems in pairs (pairs) and students are asked to share ideas (share) with other friends. According to [3] that TPS type cooperative learning is a cooperative learning model that places students in pairs to complete academic tasks through three stages, namely: think (think), pair (pair), and share (share).

According to [4] the cooperative learning model is a sequential procedure in the learning process by utilizing peers (other students) as learning resources to achieve educational goals. Furthermore, [5] states that the cooperative learning model is a form of learning activity in which students learn and work in collaborative small groups consisting of four to six people with a heterogeneous group structure. Cooperative Learning learning methods can: (a) teach students to trust the lecturer; (b) thinking ability; (c) seek information from other sources and learn from other students; (d) encourage students to express their ideas verbally and compare them with their friends' ideas; (e) helping students to learn to respect each other smart students and students who are less and can accept these differences [6].

According to [7] states that "learning motivation is the psychic power of students in order to achieve the desired goal". In line with the previous opinion, Sardiman A. M [7] also explained that learning motivation is all the driving forces of students that produce learning activities. According to Hamzah B. Uno [7] the important role of learning and learning motivation, among others: 1) Motivation to learn character is the power of learning. This type of motivation is the power of learning if a child is learning given the problem of solving and solving the help he has gone through. 2) Motivation as the role of clarifying learning objectives. 2) Motivation as the role of clarifying learning objectives. This is the meaning of a study. Children will be interested in learning, if the child at least knows the benefits of the learning process. 3) Motivation to study perseverance, children already have the desire to learn, will carry out learning activities diligently.

In addition, Oemar Hamalik [7] mentions the function of motivation includes. 1) Encouraging the emergence of behavior / an action. 2) As a director, it means to lead activities to the desired achievement. 3) As a mover, it means as a driver in learning activities. This article aims to determine the effect of the TPS type cooperative learning model on students' learning motivation at STIMI Meulaboh.

\section{The Proposed Method}

TPS type cooperative learning This study uses descriptive qualitative methods, to obtain results of the extent of influence or student response to the model. Qualitative research produces analytical data that does not need statistical analysis procedures or quantitative methods. Qualitative research is research with qualitative descriptive data collection, documentation, field notes, as well as respondent attitudes, documents and others" [8].

\section{II.1 Research sites}

This research was conducted at the STIMI Meulaboh Management Economics Study Program. The choice of place of research because the author is a permanent lecturer at the college, making it easier for the author to collect the necessary data.

\section{II.2 Population and Research Sample}

Population is the whole object to be examined in a study. The population in this study were all students of STIMI Meulaboh, while the sample of second semester students of the Management Economics Study Program was 1 (class) class that had the same ability (homogeneous). 


\section{II.3 Data collection technique}

The data in this study were collected using a questionnaire after students were taught using the TPS type cooperative learning model. Questionnaire is a technique to obtain data in the form of questions or statements for respondents. The calculation of the questionnaire in this study is using a Likert scale, where the variables are measured and translated into indicators. The type of a questionnaire in its indicators is in the form of positive and negative sentences. Each answer was given a choice of strongly agree (SA), agree (A), Normal (N), disagree (D), and strongly disagree (SD).

\section{II.4 Research Instruments}

The instrument in this study was in the form of a questionnaire. [8] stated "Research instrument is a tool in viewing natural and social phenomena that are being observed". The instrument that the researcher uses is as follows. Questionnaire, found the results of how the motivation of students and teachers towards interactive models in learning activities.

Table 1. Criteria for Statement Items

\begin{tabular}{lllllll}
\hline No & Statement & SA & A & N & D & SD \\
\hline
\end{tabular}

1. I prefer to study Economic Statistics I using the TPS type cooperative learning model.

2. TPS type cooperative learning model helps me in understanding the material.

3. I understand better how to explain using a cooperative model when learning takes place in class.

4. The use of TPS type cooperative learning makes it easy for me to understand the learning material.

5. I am a student who likes to study in groups.

6. I think learning in pairs and sharing helps stimulate learning activities.

7. I am a student who likes it when lecturers use the TPS-type cooperative learning model, which makes it easy for me to share material that I already understand and solve problems when learning Economic Statistics I.

8. I am more excited when the lecturer uses the cooperative learning model when studying Economic Statistics I.

9. TPS type cooperative learning makes me interesting in learning

10. In my opinion, learning by using TPS-type cooperative learning revives the learning atmosphere in class. 


\section{Result and Discussion}

Based on the results of processing observational data (observations) that have been carried out, the result is that there is an effect of the application of the cooperative learning model on students' learning motivation. Then the students also enjoy learning more, this can be seen when the implementation of learning takes place. Students seem to have an active interaction with lecturers reciprocally. So, it can be said that the cooperative learning model can also improve the learning atmosphere and encourage students to learn more actively.

\section{III.1 Questionnaire data results (questionnaire)}

The results obtained by using statistical quantitative methods Likert scale questionnaire techniques get results from 10 statements that must be answered by 22 respondents. Each indicator has five choices, each of which is given a score of 1-5 according to negative and positive statements.

Table 2. Value Presentation

\begin{tabular}{cc}
\hline Weight & Information \\
\hline $0 \%-1,9 \%$ & Very less \\
\hline $2 \%-3,9 \%$ & Not Enough \\
\hline $4 \%-5,9 \%$ & Enough \\
\hline $6 \%-7,9 \%$ & Good \\
\hline $8 \%-10 \%$ & Verry good \\
\hline
\end{tabular}

Giving a score of strongly agree (SA) gets 5 points, scoring on agree (A) gets a score of 4, scoring on the normal choice $(\mathrm{N})$ gets a score of 3 , scoring on the option disagree (D) gets a score of 2 , scoring strongly disagree (SD) gets a score of 1 . This scoring only applies to positive questions.

Table 3. The Average Results of Each Question in The Questionnaire Has Been Answered By 22 Samples

\begin{tabular}{llcc}
\hline No & \multicolumn{1}{c}{ Statement } & Results(\%) & Description \\
\hline 1. & $\begin{array}{l}\text { I prefer to study Economic Statistics I using the TPS } \\
\text { type cooperative learning model. }\end{array}$ & Very Good \\
& & \\
\hline 2. & $\begin{array}{l}\text { TPS type cooperative learning model helps me in } \\
\text { understanding the material. }\end{array}$ & Good \\
\hline 3. $\quad \begin{array}{l}\text { I understand better how to explain using a cooperative } \\
\text { model when learning takes place in class. }\end{array}$ & $7,8 \%$ & Good \\
\hline 4. & $\begin{array}{l}\text { The use of TPS type cooperative learning makes it easy } \\
\text { for me to understand the learning material. }\end{array}$ & $7,5 \%$ & Good \\
\hline 5. I am a student who likes to study in groups. & $7 \%$ & \\
\hline
\end{tabular}


6. I think learning in pairs and sharing helps stimulate $8,2 \% \quad$ Verry Good learning activities.

7. I am a student who likes when lecturers teach using the $8 \% \quad$ Verry Good TPS type cooperative learning model because it makes it easy for me to share material that I have understood and solve problems when learning Economic Statistics I.

8. I am more excited when the lecturer uses the $7,7 \%$ Good cooperative learning model when studying Economic Statistics I.

9. TPS type cooperative learning makes me interesting in $8,5 \% \quad$ Verry Good learning

10. In my opinion, learning by using TPS-type cooperative $\quad 7,6 \%$ Good learning revives the learning atmosphere in class.

So, from these results it is concluded that the acquisition of each statement has a good average. So, the use of cooperative learning models can help students during the process of learning activities in class. The following are the results of the questionnaire from all the questions that have been answered by 22 respondents. The criterion value obtained from 22 respondents has an average (mean).

Table 4. Value Presentation

\begin{tabular}{cc}
\hline Weight & Information \\
\hline $0 \%-1,9 \%$ & Very less \\
\hline $2 \%-3,9 \%$ & not enough \\
\hline $4 \%-5,9 \%$ & enough \\
\hline $6 \%-7,9 \%$ & good \\
\hline $8 \%-10 \%$ & Verry good
\end{tabular}

The percentage of the overall distribution of the questionnaire with 22 respondents from a sample of students who were taught the TPS type cooperative learning model was $7.9 \%$ percent. $7.9 \%$ is in the good category. This means that the use of the TPS type of cooperative learning model can help students during the learning process in the classroom. The researcher used the TPS type of cooperative learning model to determine the extent to which students were motivated by the splitting model in the economic statistics course I.

\section{Conclusion}

Based on the results of qualitative data analysis, it was concluded that the TPS type cooperative learning model had an effect on students' learning motivation. Therefore, it can be said that the TPS type of cooperative learning model is feasible to be used in the learning process of Economics I statistics in the classroom and in independent learning to improve students' understanding and quality of learning. 


\section{Acknowledgment}

Thank you to the chairperson of the STIMI Management Economics Study Program Meulaboh. My thankto my fellow lecturers who have guided and assisted in the publication of my journal. Hopefully, I get this guidance and assistance to improve my self in future journal publication.

\section{References}

[1] Kosasih, E. 2014. Learning and learning strategies. Bandung: Yrama Widya.

[2] Wikanengsih, W., Nofiyanti, N., Ismayani, M., \& Permana, I. (2015). Analysis of Learning Implementation Plans (RPP) for Indonesian Language Subjects (Study of RPP Prepared by Indonesian Language Teachers for Junior High School Level in Cimahi City). P2M STKIP Siliwangi, 2(1), 106-119.

[3] Arki, A.K.H et al. 2017. Application of the Think-Pair-Share Cooperative Learning Method to Improve Student Learning Outcomes for Class XI MIA.2 SMA Negeri 3 Takalar Model (Studies on Acid-Base Solutions). Chemical Journal. Volume 18(2), December 2017, p. 71-79. Department of Chemistry, Faculty of Mathematics and Natural Sciences: Makassar State University.

[4] Elhefni. 2011. Cooperative Learning Model Type Think Pair Share and Learning Outcomes in Schools. TA'DIB. Volume XVI (02), November 2011 Edition, p. 303-319. Faculty of Tarbiyah IAIN Raden Fatah Palembang: Palembang.

[5] Rusman. 2013. Learning Models: Developing Teacher Professionalism. 2nd Edition. Jakarta: PT. RajaGrafindo Persada.

[6] Kurnia, RD et al. 2014. Development of Cooperative Learning-Based Learning Model in Improving Student Learning Motivation and Quality Improvement of E-Learning-Based Alumni Fasilkom Unsri (case study: web programming course). Journal of Information Systems (JSI), Volume 6(1), April 2014, p. 645-654, ISSN Printed: 2085-1588, ISSN Online: 2355-4614. Information Systems Faculty of Computer Science Sriwijaya University: Sriwijaya University.

[7] Sadikin, A. 2018. The Implementation of Learning Journal to Improve University Students' Motivation in Basic and Process of Learning Biology Subject. Bioeducation Journal, 2(1), 70-75.

[8] Sugiyono. 2017. Quantitative, Qualitative, and R\&D Research Methods. Bandung: Alphabet. 